\title{
Two new records of Genus Agaricus from Western Ghats forests of India
}

\author{
R. Kantharaja, K. J. Nandan Patel, M. Krishnappa* \\ Department of PG Studies and Research in Botany, Kuvempu University, Jnana Sahyadri, Shankaraghatta, Shivamogga, \\ Karnataka 577451 , India \\ *Corresponding author Email: krishnappam4281@yahoo.com \\ (Submitted on July 25, 2020; Accepted on October 10, 2020)
}

\section{ABSTRACT}

Two species of the genus Agaricus L., each from Sect. Brunneopicti Heinem. (A. Chiangmaiensis Karun., Guinb. and K.D. Hyde) and Sect. Arvenses (Konrad and Maub.) Konrad and Maub. (A. flocculosipes R.L. Zhao, Desjardin, Guinb. and K.D. Hyde) newly reported from India. The specimens were collected from different parts of Central Western Ghats and studied by morphological, microscopic and molecular phylogenetics using nrITS and nrLSU sequences. The current study presents the descriptions, color photographs, and phylogenetic relationships.

Keywords: Agaricales; floccose; ITS; morpho-molecular; taxonomy, Western Ghats.

\section{INTRODUCTION}

Agaricus L., a genus of saprophytic fungi, commonly producing fleshy, gilled mushrooms belongs to order Agaricales (Agaricomycetes, Basidiomycota). The genus is species-rich with more than 500 species worldwide (Callac and Chen, 2018), that are edible, medicinal, and even poisonous. With the advancement in molecular phylogeny, number of investigators (Zhao et al., 2011; Chen et al., 2017; He et al., 2016; Parra et al., 2018) has revisited the classification of the genus in the past decade. Presently six subgenera and 24 sections have been recognised under genus Agaricus (Callacand Chen, 2018).

The genus Agaricus is cosmopolitan in distribution and grows in various habitats, Western Ghats of India is one of the eight global biodiversity hotspots. Bhadra Wildlife Sanctuary falling in this area is quite rich in mushroom population. A study to assess the macrofungal diversity in this area was initiated in the year 2016. Out of the collections studied two interesting species of genus Agaricus, namely $A$. chiangmaiensis (sect. Brunneopicti) and A. flocculosipes (sect. Arvenses) were documented which are being described for the first time from India (Upadhyay et al., 2017; Saini et al., 2018).

\section{MATERIALS AND METHODS}

The studied sporocarps are collected from Kakanahosudi $\left(13^{\circ} 45^{\prime} 09.0^{\prime} \mathrm{N} 75^{\circ} 33^{\prime} 07.0^{\prime} \mathrm{E}\right)$ and Chibballi $\left(13^{\circ} 43^{\prime} 59.6^{\prime} \mathrm{N}\right.$ $\left.75^{\circ} 28^{\prime} 33.1^{\prime \prime} \mathrm{E}\right)$ of Bhadra Wildlife Sanctuary, Central Western Ghats region of Karnataka during June-September, 2019.

Sampling and morphological characterization: Sporocarps encountered during the survey are collected with field notes on macro-morphological characteristics and habitat conditions were documented on the field key especially designed for the purpose (Atri et al., 2017). Collected basidiomata were subsequently dried and utilized for further characterization. Micro-morphological characters are studied using Olympus $\mathrm{CH} 20 \mathrm{i}$ binocular light microscope and subsequently identified (Zhao et al., 2012; Karunarathna et al., 2014).

DNA Extraction and PCR: Freshly collected sporocarps were used for extraction of DNA by the CTAB method (Kantharaja and Krishnappa, 2020). $100 \mathrm{mg}$ of inner tissue of the sporocarp was homogenized directly by micro-pestle (Tarsons) in a micro-centrifuge tube with $500 \mu \mathrm{L}$ of $2 \mathrm{X}$ CTAB extraction buffer at $65^{\circ} \mathrm{C}$. Vortexed for few seconds and incubated at $65^{\circ} \mathrm{C}$ for 1 hour. Slightly cooled and centrifugated at $13000 \mathrm{rpm}$ for 30 minutes. $3 \mu \mathrm{L}$ of RNase $\mathrm{A}$ is mixed with centrifugate and incubated for $10 \mathrm{~min}$ at $37^{\circ} \mathrm{C}$. $500 \mu \mathrm{L}$ of PCI $(25: 24: 1)$ (Himedia) was added to the mixture and centrifuged at $10000 \mathrm{rpm}$ for $10 \mathrm{~min}$ at room temperature. To the supernatant $600 \mu \mathrm{L}$ of ice-cold isopropanol was added and incubated overnight. To pellet the DNA the mixture was centrifuged at $10000 \mathrm{rpm}$ for 10 minutes at $10^{\circ} \mathrm{C}$. The pellet was washed twice with $70 \%$ ethanol and dissolved in $50 \mu \mathrm{L}$ of $1 \mathrm{X}$ TE buffer. The extracted DNA was analyzed for purity using $0.8 \%$ agarose gel electrophoresis and Bio-photometer (Eppendorf India Pvt. Ltd.).

PCR reactions were carried out using Eppendorf Mastercycler nexus GX2 in $0.2 \mathrm{ml}$ PCR tubes with $50 \mu \mathrm{L}$ reaction mixture containing, $25 \mu \mathrm{L}$ double distilled water, 8 $\mu \mathrm{L}$ 10X PCR buffer A(Himedia). $2.5 \mu \mathrm{L}$ of each primer, $0.5 \mu \mathrm{l}$ of Taq DNA polymerase $(3 \mathrm{U} / \mu \mathrm{L}), 1.5 \mu \mathrm{L}$ dNTP's mixture (Himedia) and $10 \mu \mathrm{L}$ of DNA template. The primer pairs ITS 1 and ITS 4 (White et al.,1990) for the nrITS region and LROR and LR5 (Vilgalys and Hester, 1990) for nrLSU region were used. The thermal profile for nrITS amplification; 4' $94^{\circ} \mathrm{C}, 32$ cycles of $30^{\prime \prime} 94^{\circ} \mathrm{C}, 1^{\prime} 52^{\circ} \mathrm{C}, 1^{\prime} 72^{\circ} \mathrm{C}$ and a final extension step of $7^{\prime} 72^{\circ} \mathrm{C}$, for nrLSU $5^{\prime} 94^{\circ} \mathrm{C}, 30$ cycles of $30^{\prime \prime}$ $94^{\circ} \mathrm{C}, 1^{\prime} 47^{\circ} \mathrm{C}, 1^{\prime} 72^{\circ} \mathrm{C}$ and a final extension step of $7^{\prime} 72^{\circ} \mathrm{C}$. The PCR products were examined on $1 \%$ Agarose gel stained with Ethidium Bromide and visualized under Gel image Documentation System (BioRad) followed by clean up and sequencing in Eurofins Genomics India Pvt Ltd.

The obtained sequences were aligned by Clustal W (Madeira et al., 2019) in BioEdit sequence alignment editor v. 7.2.5 (Hall, 1999). The consensus sequences are used for the BLAST search on the NCBI GenBank database to identify the sequence similarity and distance tree results. The sequences are deposited to GenBank.

Sequence alignment and phylogenetic analysis: Based on published literature (Kerrigan et al., 2005, 2008; Zaho et al., 2012; Karunarathna et al., 2014,) a total of 38 sequences (23 ITS and 15 LSU) were retrieved from the NCBI GenBank nucleotide database (Table $1 \boldsymbol{\&} 2$ ) and combined with newly 
Table 1: List of species, geographic origin and GenBank Accession numbers of nrITS sequences used in Molecular phylogeny analysis.

\begin{tabular}{cllc}
\hline $\begin{array}{c}\text { Sl. } \\
\text { No. }\end{array}$ & \multicolumn{1}{c}{ Species } & $\begin{array}{c}\text { Geographic origin } \\
\text { and Year }\end{array}$ & $\begin{array}{c}\text { GenBank } \\
\text { Accession No. }\end{array}$ \\
\hline 1. & Agaricus flocculosipes & India, 2019 & MN741161 \\
\hline 2. & Agaricus flocculosipes & China, 2019 & KJ162117 \\
\hline 3. & Agaricus flocculosipes & Korea, 2015 & KP004930 \\
\hline 4. & Agaricus flocculosipes & China, 2019 & KJ162113 \\
\hline 5. & Agaricus flocculosipes & China, 2019 & KJ162116 \\
\hline 6. & Agaricus flocculosipes & China, 2019 & KJ162118 \\
\hline 7. & Agaricus flocculosipes & China, 2019 & KJ162114 \\
\hline 8. & Agaricus chiangmaiensis & India, 2019 & MN741165 \\
\hline 9. & Agaricus chiangmaiensis & Belgium, 2011 & JF514531 \\
\hline 10. & Agaricus chiangmaiensis & Thailand, 2011 & KC971099 \\
\hline 11. & Agaricus sp. & Belgium, 2018 & JF514518 \\
\hline 12. & Agaricus bresadolanus & India, 2019 & MN744430 \\
\hline 13. & Agaricus romagnesii & India, 2017 & MH862192 \\
\hline 14. & Agaricus sp. & India, 2015 & KR154965 \\
\hline 15. & Agaricuscrocopeplus & India, 2019 & MN907541 \\
\hline 16. & Agaricus crocopeplus & China, 2019 & MN622742 \\
\hline 17. & Agaricus crocopeplus & China, 2013 & KF767446 \\
\hline 18. & Agaricus crocopeplus & China, 2013 & KF767447 \\
\hline 19. & Agaricus subrufescens & Mexico, 2017 & KY704306 \\
\hline 20. & Agaricus arvensis & South Korea, 2010 & HM004552 \\
\hline 21. & Agaricus macrocarpus & Canada, 2008 & MF954620 \\
\hline 22. & Agaricus excellens & Belgium, 2017 & MH861817 \\
\hline 23. & Agaricus augustus & Netherlands, 2017 & MH859051 \\
\hline 24. & Chlorophyllum molybdites & Sudan, 2019 & MK541940 \\
\hline 25. & Chlorophyllum molybdites & Sudan, 2019 & MK541941 \\
\hline & & & \\
\hline & & & \\
\hline
\end{tabular}

generated nrITS and nrLSU sequences separately to conduct phylogenetic analysis. The unaligned sequences datasets used to assess the alignment confidence score for each residue pair under MAFFT (Katoh et al., 2019) algorithm of the GUIDANCE (Sela et al., 2015) webserver (http://guidance. tau.ac.il). The alignment output is used to conduct maximum likelihood analysis using RAxMLHPC2 on XSEDE with 1000 bootstrap replications and Bayesian analysis was performed with MrBayes on XSEDE for One million generations using the $\mathrm{GTR}+\mathrm{G}+\mathrm{I}$ model as suggested by jModel Test v.2.1.10 (Darriba et al., 2012) at CIPRESS Science Gateway (Miller et al., 2010). The Bayesian posterior probabilities were calculated and trees are viewed and edited in Fig Tree v.1.4.4 (Rambaut, 2009).

Table 2: List of species, geographic origin and GenBank Accession numbers of nrLSU sequences used in Molecular phylogeny analysis.

\begin{tabular}{cllc}
\hline $\begin{array}{c}\text { S1. } \\
\text { No. }\end{array}$ & \multicolumn{1}{c}{ Species } & $\begin{array}{c}\text { Geographic } \\
\text { origin and Year }\end{array}$ & $\begin{array}{c}\text { GenBank } \\
\text { Accession No. }\end{array}$ \\
\hline 1. & Agaricus flocculosipes & India, 2019 & MN741164 \\
\hline 2. & Agaricus flocculosipes & China, 2015 & KT951463 \\
\hline 3. & Agaricus macrocarpus & Ukraine, 2017 & MH874113 \\
\hline 4. & Agaricus essettei & China, 2015 & KT951514 \\
\hline 5. & Agaricus arvensis & Netherlands, 2017 & MH872779 \\
\hline 6. & Agaricus chiangmaiensis & India, 2019 & MN741166 \\
\hline 7. & Agaricus sp. & Malaysia, 2015 & KT951482 \\
\hline 8. & Agaricus bresadolanus & India, 2019 & MN744432 \\
\hline 9. & Agaricus romagnesii & India, 2017 & MH873880 \\
\hline 10. & Agaricus subrutilescens & China, 2015 & KT951522 \\
\hline 11. & Agaricus litoralis & Spain, 2015 & KT951483 \\
\hline 12. & Agaricus litoralis & Hungary, 2018 & MK277488 \\
\hline 13. & Agaricus crocopeplus & India, 2019 & MN907636 \\
\hline 14. & Agaricus crocopeplus & China, 2013 & KF767449 \\
\hline 15. & Agaricus crocopeplus & China, 2013 & KF767448 \\
\hline 16. & Leucoagaricus crystallifer & Hungary, 2018 & MK278287 \\
\hline 17. & Leucoagaricus crystallifer & Germany, 2002 & AY176412 \\
\hline
\end{tabular}

\section{RESULTS}

During our survey, two species of genus Agaricus L.,were identified by morphological characters and molecular phylogenetic studies based on nrITS and nrLSU sequences. The initial BLAST searches of both the regions show homology with A. Chiangmaiensis and A.flocculosipes. The consensus sequences are deposited to the NCBI GenBank Submission portal (https://submit.ncbi.nlm.nih.gov/subs/genbank/).
Phylogenetic analysis: The phylogenetic study using nrITS and nrLSU sequences was conducted separately including 235 (nrITS) and 133 (nrLSU) distinct alignment patterns with $24.71 \%$ (nrITS) and $30.54 \%$ (nrLSU) proportion of gaps and undetermined characters in the aligned datasets. The final RAxML trees are shown in Fig. 1 and Fig. 2 with the final ML optimization likelihood values of -2312.66 (nrITS) and 2466.07 (nrLSU). RAxML and Bayesian analysis of both datasets resulted in phylogenetic reconstructions with highly similar topologies. The newly recorded Agaricus spp. were formed well-supported clades with $>60$ bootstrap values.

\section{Taxonomy}

Agaricus chiangmaiensis Karun., Guinb. \& K.D. Hyde, Chiang Mai Journal of Science 41 (4): 773 (2014)

\section{MycoBank number: 800272}

GenBank accession numbers: MN741165 (ITS), MN741166(LSU).

Pileus $80-160 \mathrm{~mm}$ in diameter, hemispherical to convex, white to yellowish-white, dry surface with small grey to pinkish brown triangular scales (Fig. 3-A). Context 5-10 mm thick at the attachment, white, soft. Lamellae free, crowded, 3-6 mm wide, white or light grey when young becoming dark brown to chocolate brown at maturity (Fig. 3-B). Annulus superior, prominent, two-layered, upper membranous, lower floccose, split into coarse scales forming wheel-like appearance (Fig. 3-C). Stipe 55-180 ×10-18 mm, obclavate, central, hollow or fistulose, context white. Basidiospores 7.0$9.2 \times 3.0-3.5 \mu \mathrm{m},(\mathrm{n}=20, \mathrm{Lm}=7.52 \mu \mathrm{m}, \mathrm{Wm}=3.81 \mu \mathrm{m}, \mathrm{Q}=$ $1.62-2.31, \mathrm{Qm}=1.97)$ chocolate brown, present in mass, oblong, rarely ellipsoid (Fig. 3-D, Fig. 4-A), germ pore absent, smooth, thick-walled. Basidia 20-25 × 6.5-9.5 $\mu \mathrm{m}$, clavate (Fig. 4-B), tetrasporate. Cheilocystidia 16-18 $\times$ 7-10 $\mu \mathrm{m}$, hyaline, smooth, pear-shaped (Fig. 4-C) with small cylindrical base. Pleurocystidia absent.

Habit and Habitat: Growing in groups on soil with humusrich conditions in the dry deciduous forest.

Specimen examined: India, Karnataka, Chikkamagaluru, NR Pura, Kakanahosudi (1345'09.0”N 75³3'07.0”E); Kantharaja R \& Krishnappa M - 10 Sep 2019 (KUBOTMKKR-92).

Agaricus flocculosipes R.L. Zhao, Desjardin, J. Guinberteau\& K.D. Hyde, Mycoscience 53: 302 (2012).

\section{MycoBank number: 561690}

GenBank accession numbers: MN741161 (ITS), MN741164(LSU).

Pileus $60-150 \mathrm{~mm}$ in diameter, convex or Plano-convex, cream-colored, smooth to some what rough in some cases, greyish brown to brown scales present all over the surface (Fig. 5-A), margin appendiculate with scattered partial veil remnants. Context 8-12 mm thick, white when young, becoming ochraceous to brown in age at maturity. Lamellae free, 4-12 mm wide, white to creamy pink when young and reddish-brown to dark brown at maturity. Stipe 100-140 × 8$15 \mathrm{~mm}$, hollow, yellowish-white, cylindrical with bulbous 


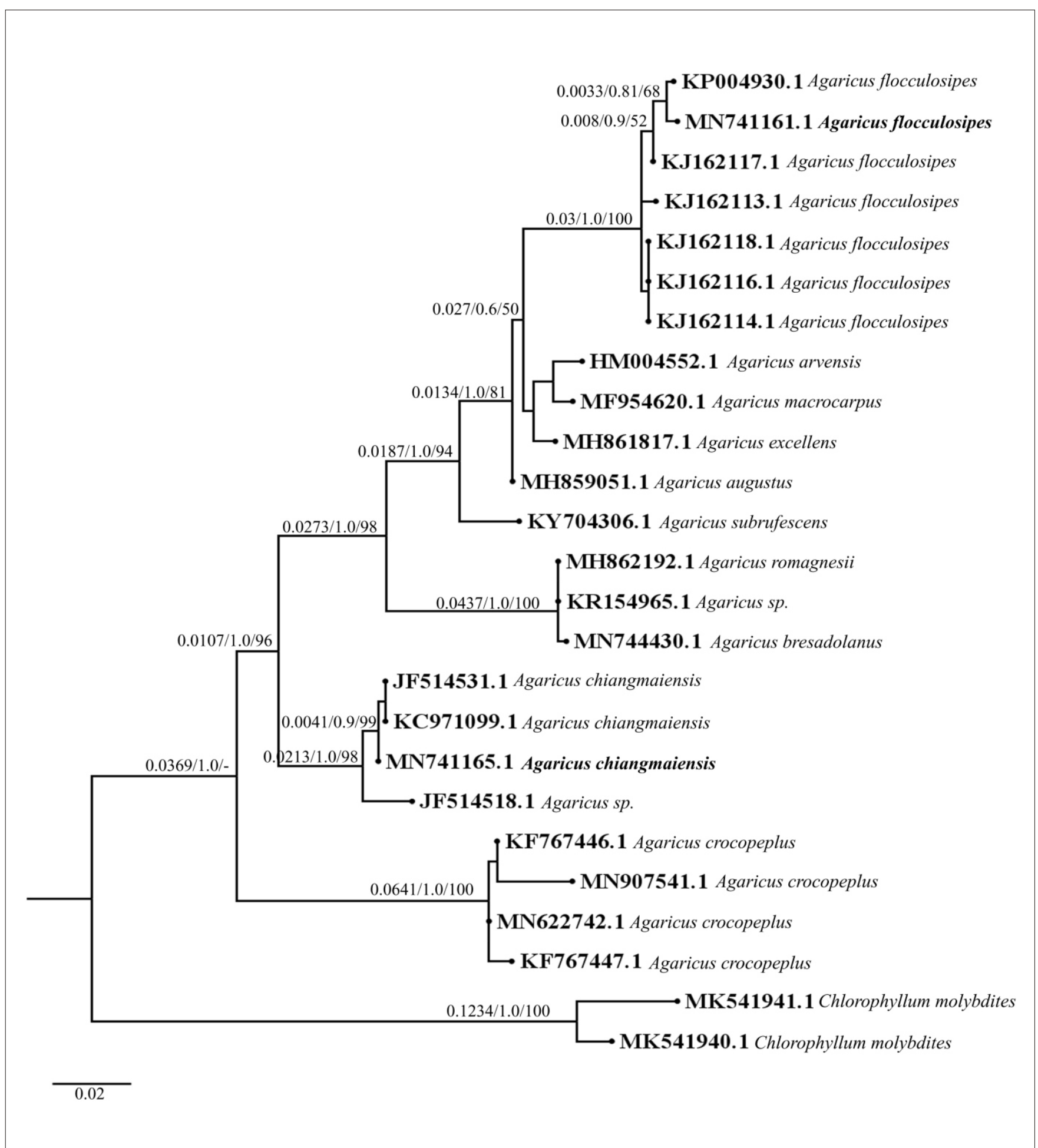

Fig. 1: RAxML tree of Agaricus spp. based on maximum likelihood analysis of nrITS sequences by GTR+G+I model with Chlorophyllum molybdites as outgroup showing Branch Length (BL), Bayesian posterior probability (PP) values $(>0.5)$ and Bootstrap Support (BS) values $(>50 \%)$. (BL/PP/BS).

base, surface covered with white flaky-floccose, erect scales below the annulus. Annulus persistent (Fig. 5-B), lower surface floccose, concolorous with stipe surface. Basidiospores 5.2-8.7 $\times 3.0-4.9 \mu \mathrm{m}(\mathrm{n}=20, \mathrm{Lm}=5.8 \mu \mathrm{m}, \mathrm{Wm}$
$=3.6 \mu \mathrm{m}, \mathrm{Q}=1.51-1.72, \mathrm{Qm}=1.61)$, smooth, ellipsoid, reddish-brown (Fig. 5-C, Fig. 6-A), no germ pore. Basidia 12-18 $\times$ 6-9 $\mu \mathrm{m}$, cylindrical to clavate $($ Fig. 6-B), tetrasporic. Cheilocystidia occasionally present, $15-25 \times 10-15 \mu \mathrm{m}$, 


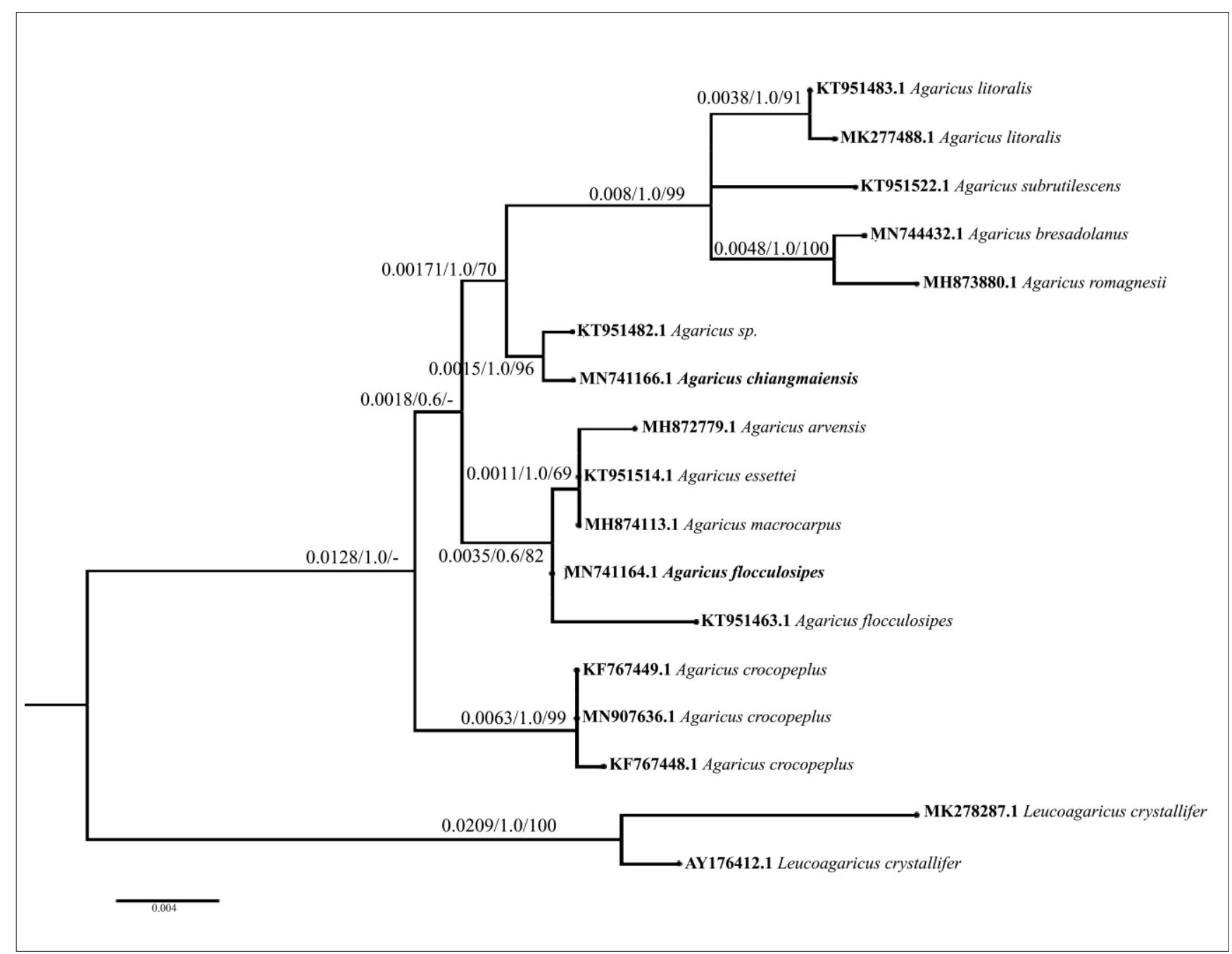

Fig. 2: RAxML tree of Agaricus spp. based on maximum likelihood analysis of nrLSU sequences by GTR $+\mathrm{G}+\mathrm{I}$ model with Leucoagaricus crystallifer as out group showing Branch Length (BL), Bayesian posterior probability (PP) values $(>0.5)$ and Bootstrap Support (BS) values $(>50 \%)$. (BL/PP/BS).

ellipsoid to clavate (Fig. 6-C), smooth, Pleurocystidia absent. Pileipellis 5-10 $\mu \mathrm{m}$ wide, hyphae cylindrical, straight or sometimes curved.

Habit and Habitat: Growing scattered on decaying leaf litter in the dry deciduous forest.

Specimen examined: India, Karnataka, Chikkamagaluru, NR Pura, Chibballi (1343'59.6”N 75²8'33.1'E); Kantharaja R \& Krishnappa M - 15 Sep 2019 (KUBOTMKKR-121).

\section{DISCUSSION}

Agaricus chiangmaiensis was first described from the Chiang Mai province of Thailand. The species is characterized by triangular dot-like scales on the surface of the pileus, duallayered annulus forming a wheel-like appearance and granular scales on the stipe (Karunarathna et al., 2014). The taxonomic details of the Indian material generally confirms with the original description of the species except for the size of the stipe. The Indian collection possesses a slightly thin and lengthy stipe in comparison to the description of the stipe provided in the original description (Karunarathna et al., 2014). Such differences are usually due to the variation in the ecological and nutritional factors. In the phylogenetic study using ITS sequences the newly generated sequences did cluster with the original sequences from Thailand (KC971099) and a sample submitted to the National Botanic Garden of Belgium (JF514531). The alignment shows only two nucleotide differences between Thai and Indian sequences.

Agaricus flocculosipes is a species with a large geographical distribution range (Gui et al., 2014) and a potentially cultivable species from Thailand. Three species of section Arvenses are characterized by the nature of annulus having a colored cap; A. subrufescens, A. augustus, and $A$. flocculosipes (Zhao et al., 2012). The species can easily be distinguished from $A$. arvensis by light brown to brownishorange grain like tiny scales. The taxonomic details of the Indian sample are in agreement with the original description provided by Zhao et al., 2012. The phylogenetic study shows newly generated nuclear ribosomal ITS sequences forming a 


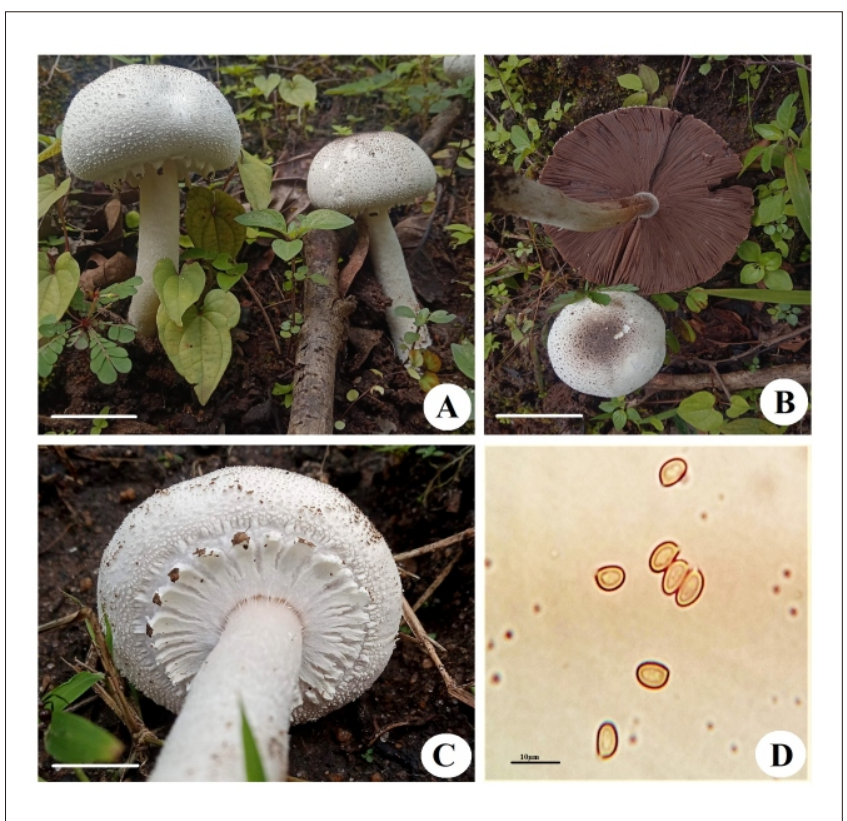

Fig. 3: Agaricus chiangmaiensis; A-B Sporacarp in habitat, C. Wheel like annulus, D. Basiodiospores. Scale Bar; A$\mathrm{C}=5 \mathrm{~cm}, \mathrm{D}=10 \mu \mathrm{m}$.

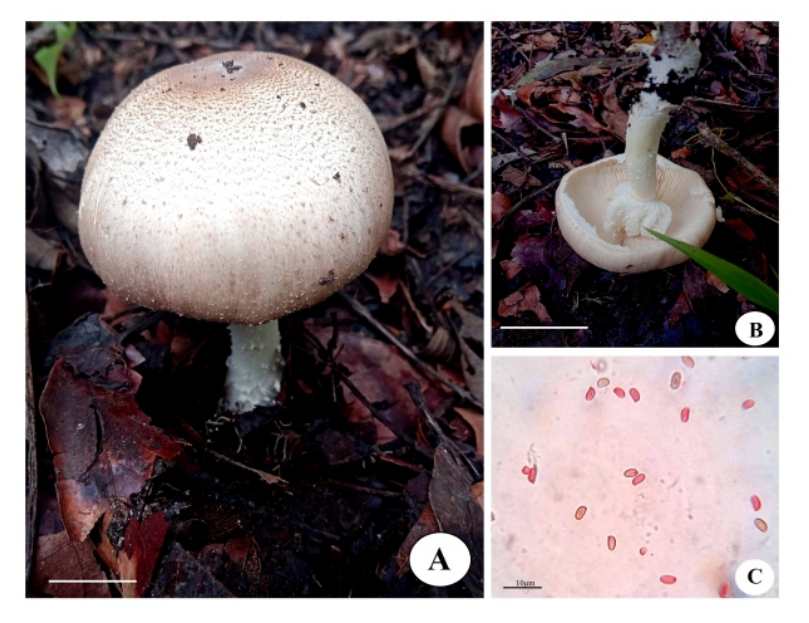

Fig. 5: Agaricus flocculosipes; A-B Sporacarp in habitat, C. Basiodiospores. Scale Bar; A-B $=5 \mathrm{~cm}, \mathrm{C}=10 \mu \mathrm{m}$.

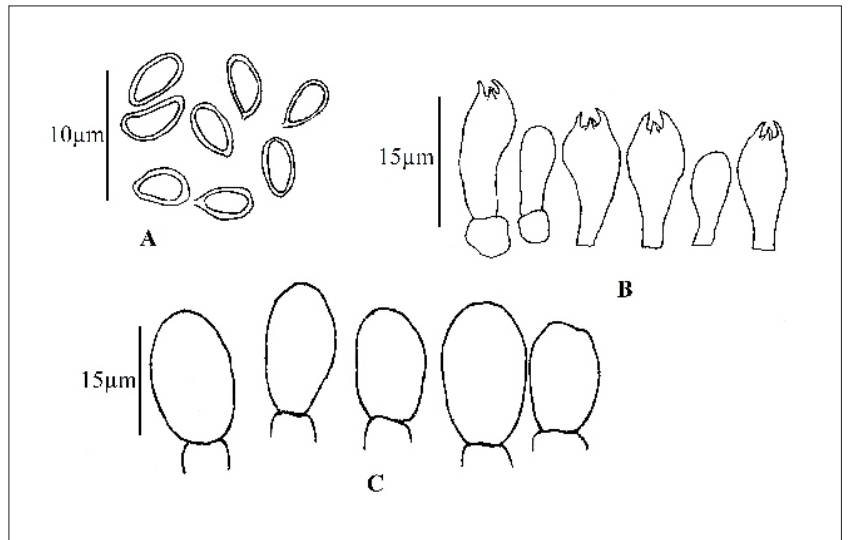

Fig. 6: Agaricus flocculosipes; A. Basiodiospores, B Basidia, C. Cheilocystidia

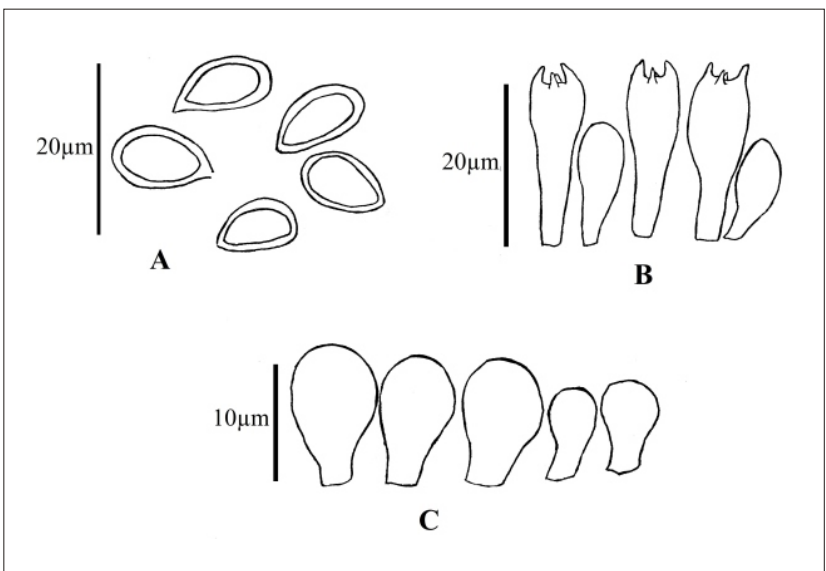

Fig.4: Agaricus chiangmaiensis; A. Basiodiospores, B. Basidia, C. Cheilocystidia.

cluster with original sequences from Thailand with more than $60 \%$ bootstrap support and high Bayesian PP value $(>0.8)$. Hence, based on the conclusions drawn from morphological and molecular studies, the Indian sample is identified as $A$. flocculosipes.

Phylogenetic analysis by nuclear ribosomal RNA large subunit gene shows grouping in respective sections (sect. Brunneopicti for A. Chiangmaiensis and sect. Arvenses for $A$. flocculosipes) this further confirms the identity of the species.

\section{ACKNOWLEDGMENTS}

The study is supported by the Department of Science and Technology, Science and Engineering Research Board (DSTSERB). Govt. of India, through project grant (EEQ/2016/ 000363).We acknowledge support from the Department of Botany, Kuvempu University, Shankaraghatta, Karnataka to carry out the research.

\section{REFERENCES}

Atri, N.S., Kaur, M. and Sharma, S. 2017. Characterization of Lamellate Mushrooms - An Appraisal. In: Developments in Fungal Biology and Applied Mycology (Eds.: Satyanarayana, T., Deshmukh, S. and Johri, B.N.). Springer, Singapore: 471-500.

Callac, P. and Chen, J. 2018. Tropical species of Agaricus. In: Sanchez, J.E., Mata, G. \& Royse, D.J. (Eds.) Updates on tropical mushrooms. Basic and applied research. San Cristobal de Las Cascaas, Chiapas, pp. 25-38.

Darriba, D., Taboada, G.L., Doallo, R. and Posada, D. 2012. jModel Test 2: more models, new heuristics and parallel computing. Nature Methods 9(8): 772.

Gui, Y., Zhu, G.S., Callac, P., Hyde, K.D., Parra, L.A., Chen, J., Yang, T.J., Huang, W.B., Gong, G.L. and Liu, Z.Y. 2014. Agaricus section Arvenses: three new species in highland subtropical Southwest China. Fungal Biology 119: 79-94.

Hall, T.A. 1999. BioEdit: a user-friendly biological sequence 
alignment editor and analysis program for Windows 95/98/NT. Nucleic Acids Symp Ser. 41:95-8.

He, M.Q., Chen, J. and Zhao, R.L. 2016. Two new records of Agaricus from Southwest China. Mycotaxon 131: 871-880.

Kantharaja, R. and Krishnappa, M. 2020. Morphological and molecular phylogenetic studies on Battarrea phalloides (Agaricales): a new report to Indian mycobiota. Journal of Threatened taxa 12(8):15881-15888.

Karunarathna, S.C., Guinberteau, J., Chen, J., Vellinga, E.C., Zhao, R.L., Chukeatirote, E., Yan, J., Hyde, K.D. andCallac, P. 2014. Two New Species in Agaricus Tropical Clade I. Chiang Mai J. Sci. 41(4): 771-780.

Katoh., Rozewicki and Yamada. 2019. MAFFT online service: multiple sequence alignment, interactive sequence choice and visualization. Briefings in Bioinformatics 20:1160-1166.

Kerrigan, R.W., Callac, P., Guinberteau, J., Challen, M.P. and Parra, L.A. 2005. Agaricus section Xanthodermatei: a phylogenetic reconstruction with commentary on taxa. Mycologia 97: 1292-1315.

Kerrigan, R.W., Callac, P. and Parra, L.A. 2008. New and rare taxa in Agaricus section Bivelares (Duploannulati). Mycologia 100: 876-892.

Madeira, F., Park, Y., Lee, J., Buso, N., Gur, T., Madhusoodanan, N., Basutkar, P., Tivey, A.R.N., Potter, S.C., Finn, R.D. and Lopez, R. 2019.The EMBL-EBI search and sequence analysis tools APIs in 2019. Nucleic Acids Research 2:47(W1), W636W641.

Miller, M.A., Pfeiffer, W. and Schwartz, T. 2010. Creating the CIPRES Science Gateway for inference of large phylogenetic trees. Proceedings of the Gateway Computing Environments Workshop (GCE), 14 Nov. 2010, New Orleans, LA: 1 - 8.
Rambaut, A. 2009. Fig Tree version 1.3.1 [computer program] http://tree.bio.ed.ac.uk

Saini, M.K., Kaur, H. and Malik, N.A. 2018. The Genus Agaricus (Agaricaceae, Agaricales) from India-A Check List. Kavaka 51:49-58.

Sela, I., Ashkenazy, H., Katoh, K. And Pupko, T. 2015. GUIDANCE2: accurate detection of unreliable alignment regions accounting for the uncertainty of multiple parameters. Nucleic Acids Research. 43 (Web Server issue): W7-W14.

Upadhyay, R.C., Verma.B., Sood,S., Atri, N.S., Lakhanpal, T.N. and Sharma, V.P. 2017. Documentary of Agaricomycetous Mushrooms of India (Orders: Agaricales, Boletales and Russulales). Jaya Publishing House, Delhi-110095.

Vilgalys, R. and Hester, M. 1990. Rapid genetic identification and mapping of enzymatically amplified ribosomal DNA from several Cryptococcus species. Journal of Bacteriology 172: 4238-4246.

White, T.J., Bruns, T., Lee, S. and Taylor, J. 1990. Amplification and Direct Sequencing of Fungal Ribosomal RNA Genes for Phylogenetics. In PCR Protocols. (Eds.: Innis,Gelfand, M. D. Sninsky, J. and White T.) NewYork, NY: Academic Press, Inc. 315-322.

Zhao, R.L., Karunarathna, S., Raspe, O., Parra, L.A., Guinberteau, J., Moinard, M., De Kesel, A., Barroso, R., Courtecuisse, R., Hyde, K.D., Guelly, A.K., Desjardin, D.E. and Callac, P. 2011. Major clades in tropical Agaricus. Fungal Diversity 51: 279-296.

Zhao, R.L., Hyde, K.D., Desjardin, D.E., Raspe, O., Soytong, K., Guinberteau, J., Karunarathna, S.C. andCallac, P. 2012. Agaricus flocculosipes sp. nov., a new potentially cultivatable species from the palaeotropics. Mycoscience 53 (4): 300-311. 